\title{
КОМУНІКАТИВНИЙ КУРС ПОЛЬСЬКОЇ МОВИ ДЛЯ ІНОЗЕМЦІВ: ПРОФІЛЬ ПІДРУЧНИКА ТА КОМПЕТЕНЦІЇ ВИКЛАДАЧА І СЛУХАЧА
}

Брацкі А. 3. Комунікативний курс польської мови для іноземців: профіль підручника та компетенції викладача і слухача.

Стаття зосереджується на специфіці побудови і проведення комунікативного курсу польської мови та супутніх занять у рамках діяльності українських шкіл / курсів іноземних мов. До уваги береться відповідність змістового наповнення підручника до вимог програм згаданих курсів та очікувань слухачів. Доводиться, що спрощена i вибіркова формула подання матеріалу в такому підручнику може не співпадати з компетенціями викладача та рівнем підготовки слухача.

Ключові слова: польська мова, комунікативний курс, підручник іноземної мови, мовна компетенція.

Брацки А. 3. Коммуникативный курс польского языка для иностранцев: профиль учебника и компетенции преподавателя и слушателя.

Статья сосредотачивается на специфике построения и проведения коммуникативного курса польского языка и сопутствующих занятий в рамках деятельности украинских школ / курсов иностранных языков. Во внимание берется соответствие содержимого наполнения учебника требованиям программ упомянутых курсов и ожиданиям курсантов. Доказывается, что упрощенная и выборочная формула подачи материала в таком учебнике может не совпадать с компетенциями преподавателя и уровнем подготовки слушателя.

Ключевые слова: польський язык, коммуникативный курс, учебник иностранного языка, языковая компетенция.

Bracki A. Z. Communicative Polish language courses for foreigners: textbook's profile and teacher's and listener's competence.

The article focuses on the specifics of the construction and communication of Polish language courses and associated activities as a part of the Ukrainian School / Courses of Foreign Languages. They consider the semantic content of a textbook compliance with the requirements of the programs mentioned courses and expectations of students. It is shown 
that the simplified formula and selective presentation of the material in this manual may not match the competencies of teacher training and the level of the listener.

Key words: Polish language, communicative language course, foreign language textbook, language competencies.

Предметом вивчення в цій статті є взаємозв'язок між способом подання матеріалу, передбаченого посібниками комунікативного курсу польської мови (як іноземної), а також компетенцією особи, що веде курс, та слухачем, який такий курс відвідує. Об'єктом роботи серед багатьох аналогів на видавничому ринку Польщі вибрано серію підручників комунікативного курсу польської мови «Hurra po polsku 1, 2, 3» 3 доданими до них зошитами вправ, компакт-дисками й посібниками для викладачів. Метод досліджень у такому разі - це зіставний аналіз рівня реалізації даного курсу, форми подання та пояснення матеріалу щодо бажаної і фактичної компетенції особи, яка веде курс, а також рівня перцепції потенційного слухача такого курсу. Очікувані результати містять комплексну діагностику позитивних i негативних наслідків використання цих підручників для викладання польської мови як іноземної на комунікативному рівні 3 урахуванням специфіки та реальних потреб українського ринку. Новизною запропонованої роботи є фактична відсутність такого аналізу, який враховує досвід викладання польської мови як іноземної у специфічному українському середовищі.

На початку варто відзначити, що польський видавничий ринок пропонує досить широкий спектр підручників і вишівських зошитів для вивчення польської мови. Починаючи від добре відомого в Україні «Podręcznika języka polskiego dla środowisk rosyjskojęzycznych» Бланки Конопки (Варшава, 1999), через цілі серії зошитів від рівня А1 до В2, таких як «Polski krok po kroku» Івони Стемек, Анни Стельмах та ін. (Краків, 2005-2012), завершуючи широким спектром пропозицій краківського видавництва «Universitas», де разом з багатьма підручниками і навчальними посібниками суто академічного спрямування, є добре відома в Україні серія «Hurra po polsku 1, 2, 3».

У рамках цієї серії, розрахованої на проведення комунікативного курсу польської мови на рівнях A1, A2 і В1, у руки викладача і студента потрапляє комплект книг, зошитів і компакт-дисків, а додатково вчитель отримує окремий зошит з інструктажем і набір тестів-зразків. Саме така взаємодоповнюваність та формально солідне опрацювання програми i процесу навчання (кожна книга розділена на чотири частини, які закінчуються тестами, додатково кожна книга закінчується узагальненим тестом) $є$ причиною вибору цієї серії для нашого аналізу. Іншим, не менш важливим аргументом, є те, що серія книжок «Hurra po polsku» на сьогодні $\epsilon$ найбільш широко використовуваним матеріалом для проведення комунікативних 
курсів польської мови в українських школах / курсах іноземних мов.

Наш аналіз проводиться у трьох руслах: 1) профілю підручника; 2) компетенцій викладача; 3) компетенцій слухача. Завдяки цьому можна подивитися на відповідну узгодженість усіх трьох елементів навчального процесу. Профіль підручника в цьому разі було визнано не стільки елементом рівним компетентності осіб, які проводять або слухають курси, скільки як обов'язковий елемент у разі використання тільки цього інструмента як бази для курсів. Основний акцент робиться на ті елементи, які вже розглядалися в інших дослідженнях і наших попередніх роботах $[1 ; 4 ; 6 ; 9 ; 16 ; 18]$, та передусім на прозорості й обгрунтованій корисності впровадженого матеріалу, ураховуючи потенційну можливість його засвоєння й розподілу на тематичні блоки. У зв'язку з комунікативним спрямуванням цих курсів здалося важливим поглянути на наявність, спосіб введення та запропоновані способи засвоєння елементів, що описують менталітет, культуру і спосіб життя, що також було предметом вивчення в попередніх роботах $[3 ; 5 ; 9 ; 10 ; 11]$.

Нарешті, не менш важливим для нас був прошарок того, що можна перекласти, чому присвячено багато місця в роботах, де об'єктом аналізу були як елементи сучасності, так і спадщина далекого минулого [2; 7; 8; $12 ; 13 ; 14 ; 15 ; 17]$. Останній 3 цих елементів стосується питання про компетенцію викладача та рівень підготовки слухача до сприйняття певного матеріалу, отож, у нашій роботі приклади, знайдені в посібнику, ілюструватимуть саме аналіз компетенцій вчителя і слухача.

\section{1. Профіль підручника.}

У післямові автори зазначають, що «Нurra» становить серію навчальних посібників для курсів 3 комунікативним профілем і з'явилася внаслідок відсутності на видавничому ринку Польщі публікацій такого типу на зразок стандартів навчання та організаційних систем «Cambrigde ESOL» та «Goethe Institut Internationes». Оскільки ідея створення вказаної серії зародилася серед працівників краківської мовної школи «PROLOG», слід визнати, що ці книги можуть бути використані для навчання польської мови як за кордонами Польщі, так і на курсах для іноземців у Польщі.

Повний курс (3 книги + 3 зошити вправ) повинен підготувати іноземця використовувати польську мову в повсякденному спілкуванні (автори підкреслили, що змоделювали в цьому разі досвід англійських і німецьких колег). Формально він мав дати слухачам знання, які дали б змогу подолати перший сертифікований іспит на рівні В1. У реальності, яку ми знаємо 3 українських шкіл / курсів іноземної мови, що організують курси польської мови, основну групу слухачів формують учні останніх класів середньої школи, які вирішили після випускних іспитів у школах почати навчання (на різних напрямках) у польських вищих навчальних закладах.

Остання заувага вказує на явний конфлікт профілю підручника () А. 3. Брацкі, 2013. 
(i курсів) з очікуваннями слухачів, тому що знань польської мови на комунікативному рівні може бути достатньо лише якщо потенційні іноземні студенти навчаються в Польщі іноземною мовою (наприклад, англійською), а так буває далеко не завжди. Щодо використання польської запропонований курс мови у кращому разі може дати іноземцю змогу обмінятися ідеями під час перерв між заняттями або задовільнити щоденні побутові потреби, проте його не достатньо, щоб засвоювати академічні знання, які подаються польською мовою. Сумнівним є також те, що підготовчі курси (зазвичай строком в один місяць), організовані в польських університетах для осіб, які вже мають сертифікат знання польської мови на рівні В1 або В2 і склали вступні іспити на потрібну спеціальність, можуть заповнити відповідні прогалини у знаннях іноземців-першокурсників.

Схоже, що автори аналізованої серії розуміють цю проблему, тому що вони намагаються вкласти в підручники і зошити дуже об'ємні теми. Вони охоплюють практично всі важливі аспекти життя і такі питання, як освіта, подорожі, повсякденні покупки й серйозні інвестиції - придбання майна, ремонт житла, вибір професії та розвиток кар'єри. Однак такий широкий підхід до питання зумовлює очевидні обмеження (вузька лексична база) і впливає на безладне розташування матеріалу. Наприклад, у 15 уроці підручника (3/4 передбаченого курсу) «Hurra po polsku 1» обговорюється анатомія людини, де лексика подається разом з ілюстративним матеріалом (підписи до зображення людської фігури) вибірково, а серед запропонованих лексем немає таких уживаних слів, як: szyja (укр. шия), biodro (укр. стегно, кульшовий суглоб), иdо (укр. стегно), tydka (укр. литка), pięta (укр. n'ята), а поруч із малюнком долоні бракує слів: pięść (укр. кулак), garść (укр. жменя), укр. nadgarstek (укр. зап'ястя). Крім того, у всіх трьох частинах слухач не знайде назв пальців, важливих для повсякденного життя хоч би на рівні фразеологічних сполук: trzymać (za kogo, co) kciuki (укр. тримати (за когось, щзось) кулаки); тіес́ (со) w małym palcu (дослівно: мати (щось) в мізиниі, добре на чомусь знатися, укр. як свої n'ять пальців) тощо.

Помічений хаос у впровадженні матеріалу супроводжується відсутністю послідовності в його поданні на рівні граматики і загалом знань про мову. Це має особливо негативні наслідки в реалізації вказаних елементів за допомогою тематичних текстів і вправ.

Наприклад, кількісні числівники подаються в «Hurra po polsku 1» щонайменше непродумано: в діапазоні від 1 до 10 на Уроці 1 (стор. 12), в діапазоні 11-23 на Уроці 2 (стор. 22), в діапазоні 20-100 на Уроці 4 (стор. 32), 100-1000 на Уроці 6 (стор. 52). Водночас порядкові числівники вводяться фактично одним блоком - в діапазоні 0-24 (на позначення добового циклу) на Уроці 7 (63-65) і 0-2000 (на позначення часу в сенсі 3 урахуванням дати, назви днів і місяців або ж дати випуску програми на TV) на Уроці 8 (стор. 66-67). 
На особливу увагу заслуговує тут помітна невідповідність зазначеного вище розподілу кількісних числівників на 4 групи, які, на думку авторів, обслуговують різні елементи повсякденного життя, з матеріалом для вправ. Поруч із числівниками 1-10 наведені тризначні номери (наприклад, компоненти телефонного номеру), поруч із 11-23 (до речі, виокремлення цього діапазону не зовсім зрозуміле) наведено коди деяких польських міст і провінцій (хоч загал цих чисел набагато ширший), 20-100 - одна 3 вправ взагалі стосується кількісних числівників 1-20, у групі 100-1000 знову з'являються телефонні номери, які тільки в цьому місці можуть бути правильно прочитані.

Такі ж зауваження стосуються загалу граматичного матеріалу, поданого шматками, що в результаті не сприяє загальному компактному сприйняттю, змушуючи викладача і слухача постійно гортати сторінки підручника в пошуках граматичних правил. Крім того, подекуди вражає непропорційність змісту уроків (кількість сторінок одного уроку коливається від 3 до цілих 12). Зрозуміло, що це викликане прагненням дотриматися схеми тема = урок, але деякі теми просто неможливо вкласти в один, а навіть два уроки.

Потенційна користь від такого розташування матеріалу пов'язується 3 природнім спрямуванням слухача пов'язувати тему 3 конкретним граматичним матеріалом, що, безсумнівно, є гарною вправою для пам'яті та будує образ певного поняття у співвідношенні з певним лексичним простором. Після багаторазового вивчення змісту всіх трьох частин значно знижується почуття дискомфорту, пов'язане 3 пошуком конкретного матеріалу, але це водночас може призвести до небажаного пов'язання лише вузької тематичної лексики з універсальною все ж таки граматичною категорією. Розв'язати цю проблему можна було б шляхом додання окремих граматичних таблиць.

\section{2. Компетенції викладача.}

Комунікативний курс мови за своєю суттю містить значний реалієзнавчий шар, який вимагає від викладача наявності глибоких знань історії, сьогодення й ментальності, пов'язаних із презентованим простором мови. Важливою складовою цих знань $є$ гарний орієнтир у звичаях, традиціях і культурі, що відбиваються в мові. Додатково на ці царини нашаровуються практичні знання про повсякденне життя (у нашому разі польське), які неможливо здобути під час академічних занять; вони вимагають більш тривалого перебування за кордоном і здобуття цих знань шляхом спостереження та безпосередньої участі в житті на чужині, якщо, звичайно, викладач не $є$ носієм цієї мови.

Підручники 3 серії «Hurra po polsku» ставлять у цьому контексті певні вимоги до викладача, які найкраще ілюструє матеріал Уроку 83 «Hurra po polsku 1», де обговорюється тема подорожей, поїздок i транспортних засобів. На сторінках 73-75 подається багата лексика зі 
сфери залізничного транспорту, але іiі ілюструє лише копія квитка на експрес-потяг. Учитель, який не знає специфіки польської залізниці й очевидних відмінностей у пасажирських перевезеннях у Польщі та в Україні, може не впоратися з поясненням багатьої кількісно інформації, наведеної у книзі як зрозумілої, щодо: а) типів поїздів, б) різниць у значенні спальний і загальний вагон, пасажирське купе, в) різниць між квитком і плацкартою в польських та українських реаліях тощо.

У рамках Уроку 1 вчитель має справу з відсутньою ланкою у звіті про основні особисті дані, оскільки підручник (стор. 14) перераховує NIP (ідентифікаційний номер платника податків), поштовий індекс, адресу, але замість нормального в усіх офісах питання про PESEL (індивідуальний номер людини), який мають усі польські громадяни та іноземці, що отримали право на постійне проживання в Польщі, автори підручника згадали реєстраційний номер автомобіля.

Таким же недоліком підручника, який обов'язково повинен пояснити вчитель слухачеві, є відсутність послідовності у використанні формальних та розмовних форм, таких як, наприклад, прямі звертання. Хоч уже Урок 0 (стор. 8) уводить основні граматичні поняття польською і латинською мовами (до речі, це дуже гарна ідея, що дає змогу кожному зрозуміти, про які саме частини мови або граматичні відмінки йдеться) та показує 7 відмінків, усе одно вже у змісті «Hurra po polsku 1» форми прямого звертання, що вимагають кличного відмінка, подаються раз відповідно до граматичного стандарту (стор. 113 - Droga Aniu!, Kochana Ciociu!), а інший раз - у розмовній формі (стор. 17 - Cześć, Ewa!; стор. 113 - Cześć Wojtek!). До того ж іще 3 непослідовною й різною пунктуацією (у прямому звертанні необхідна кома перед ім'ям того, до кого звертаються). Учителю просто необхідно знати, що використання кличного відмінка в цьому разі визначається стилістично: у щоденній польській мові використовують цю форму для того, щоб додати фразі формальності та висловити повагу до адресанта, а використання називного відмінку вказує на певну ступінь близькості взаємин.

Складніше завдання постає перед вчителем у контексті відсутності опису в підручнику знаків пунктуації при одночасному поданні основних символів, що використовуються в інтернеті (Урок 4, стор. 33, 40). Варто відзначити, що тексти, включені до матеріалів різних уроків, містять усі знаки пунктуації. Видається доцільним назвати їх так само, як були названі частини мови та інші основні граматичні категорії.

Аналогічна проблема стосується Уроку 11, де на стор. 93 слухач має навчитися писати і читати СМС-повідомлення польською мовою. Учитель повинен знати, що переважна частка текстових повідомлень такого типу створюється без використання польських діакритичних знаків, а це (за винятком літери $\mathrm{V}$ - у польській абетці вона пишеться виключно в 
запозиченнях, а в рідних або асимільованих словах пишеться W) наближує цей «польський запис» до латинської абетки. Тут помітна непослідовність авторів підручників, які не уникають форм розмовної мови, але водночас навчають слухача (певною мірою також учителя), що текст СМС «по-польськи» пишеться добірною польською мовою.

На кінець цієї частини варто нагадати, що в будь-якій мові трапляються неоковирні словосполучення. Хоч їх вживають кожного дня самі користувачі, вони все одно не перестають бути незграбними. До таких фраз у польській мові належить вислів uprzejma prośba укр. ввічливе / люб'язне прохання, яке часто використовується в текстах заяв, подань і т. ін. Це типовий приклад тавтології, тому що прохання вважається по суті ввічливим, а неввічливе прохання, це, наприклад, вимога. Однак автори в Уроці 18 першої частини на стор. 146 вписують саме цю фразу в зразок подання, автором якого $є$ німець (Даміан Гроп), який хоче отримати стипендію. Зі змісту цього подання ми дізнаємося, що він є студентом європейської культурології та вивчає польську мову протягом півроку, але це жодним чином не пояснює використання тієї форми, хіба що Даміану допоміг написати лист малоосвічений поляк.

Мимоволі посилюється переконання, що викладачем таких курсів має бути поляк або іноземець (наприклад, українець), який дуже довго жив у Польщі. Рівень знань про сучасну Польщу, відсутній у підручнику, але який необхідно мати людині, що веде курси, вражає. Це практичні знання про транспорт (квитки на міську і приміську зони, на час, на певний період і т. ін.), житло (професійна лексика в галузі проектування будівель і споруд), сучасна польська політика та соціальні питання тощо. А це лише підручник для навчання основ польської мови.

\section{3. Компетенції слухача.}

3 попередніх двох частин вимальовується діапазон бажаних компетенцій слухачів цих курсів. Це має бути людина з базовими знаннями граматики (принаймні) однієї 3 сучасних європейських мов, у якій відсутні аналітичне відмінювання та постпозитивні артиклі, оскільки запропонований у курсі граматичний матеріал дуже обмежений. Українці серед слов'ян мають досить просте завдання, тому що граматика їх рідної мови має багато збігів 3 польською граматикою, а найважчим цей курс буде для болгар і македонців.

Проблемою натомість є бажані хоч би основні знання про різновиди мови (передусім - соціальні діалекти) та риси цих різновидів. Автори заглиблюються у проблему лише тоді, коли вказують на стиль висловлення офіційний і загальний та неформальний. Студент повинен самостійно дійти висновку, що офіційний стиль буде близький до літературного стандарту (хоч у польській традиції вказується на письмовий i усний варіант літературної мови), універсальний стиль більш-менш відповідатиме поняттю 
загальної мови (занижений стандарт повсякденного вжитку) і неформальний стиль, який є по суті злиттям розмовної мови й соціальних діалектів. Швидше за все вчитель не знайде час, щоб пояснити такі нюанси. Незалежно від вроджених здібностей українських студентів важко собі уявити, що вони мають такі знання про польський мовний простір.

Помітне досягнення відповідної серії підручників полягає у зміцненні гарної слухової й візуальної пам'яті учня та постійне тренування їі шляхом вправ, де вимагається доповнити відсутні елементи тексту (слова, букви). За відсутності повної інформації про польський правопис, де той же або аналогічний звук записується двома способами ( $r z-\dot{z} ; \dot{o}-u ; c h-h$ тощо), про фонетичну асиміляцію, де запис не відповідає вимові ( $r z$ після приголосних читається як $\check{s} ; w$ поруч з глухою приголосною або в кінці слова читається як $f$ тощо) слухач повинен розвинути в собі здатність запам'ятовувати приклади i послуговуватися ними як аналогами при вирішенні завдань. В українців, які, використовуючи кирилицю, пишуть так, як чують, уява має постійно працювати.

Короткі згадки про історію Польщі спричиняють до того, що слухач змушений самостійно дійти деяких висновків у процесі засвоєння конкретного матеріалу. Гарним прикладом є Урок 16 з підручника «Hurra po polsku 2», де на стор. 132 у вигляді піктограм зображено традиційні свята національні, релігійні, сімейні - та запропоновано підписати ці зображення відповідними назвами свят. Поряд 3 християнської Пасхою і Різдвом 3'являється єврейське Йом-Кіпур (івр. День очищення, День Спокути, Судний день) або Шабат (за Торою сьомий день тижня, коли слід відпочивати). Звичайно, немає нічого поганого у відзначенні, що єврейська культура (особливо у великих містах, таких як Краків, Люблін та Варшава) відіграла важливу роль у польській історії, але ми не можемо забувати, що вона не стала частиною польської культури. Важко уявити собі єврея, який святкує Різдво, і поляка (зазвичай християнина), який святкує Йом-Кіпур. У підручнику забракло саме такої простої інформації, звідси висновок, що студент сам повинен це розуміти.

На закінчення варто відзначити: незважаючи на недоліки, виявлені в cepiï «Hurra po polsku 1, 2, 3», цей підручник $є$ одним 3 кращих для навчання польської мови на рівні комунікативного курсу. Кілька помилок у записі слід віднести до так званих друкарських, а деякі застарілі відомості розуміти як результат об'єктивних змін у Польщі (телефонні коди, назви різновидів поїздів тощо). Це значний крок у правильному напрямку, оскільки кожен наступний комунікативний курс польської мови має в цій серії цінний і повчальний орієнтир.

Виявлені та проаналізовані недоліки пов'язані з відсутністю перспективи, досвіду i традиції таких опрацювань у Польщі. Бажання забезпечити максимально широкий спектр матеріалів та своєрідна універсалізація 
підручника спричиняе те, що він не буде кращим для конкретного (наприклад, українського) ринку, а тільки хорошим на більшості ринків. Як на рівні граматичного матеріалу, так і лексики чи тематики очевидними $\epsilon$ узагальнення, що, звичайно, обтяжує викладача курсів додатково обов'язком пояснити ці нюанси, змушує його продемонструвати чудові знання сучасної польської дійсності.

Слухач має продемонструвати значну активність у пошуку відповідей на конкретні теми. Він повинен мати деякі уявлення про польські реалії, здобувати багато інформації, відсутньої в цьому посібнику, повинен мати хорошу мовну інтуїцію та хорошу зорову і слухову пам'ять.

Отже, найбільш важливим прагматичним аргументом на користь визнання важливості й цінності циклу «Hurra po polsku 1, 2, 3» та аналогічних публікацій є безпрецедентна популярність польської мови не тільки серед філологів і не тільки серед українських студентів при одночасній невідповідності дій закордонної полоністики стосовно виниклої ситуації. Результатом є формування плеяди приватних шкіл / курсів іноземних мов, які пропонують тільки (або головним чином) курси польської мови. Брак наукових кадрів, добре підготовлених до ведення таких курсів, очікування осіб, зацікавлених проходженням такого курсу, що переростають компетенції викладачів цих курсів i водночас неможливі для реалізації через низький рівень філологічних знань потенційних слухачів - усе це змушує подивитися по-іншому на функціонування польської мови за межами Польщі. Згадані проблеми формують найважливіший висновок, що справжній орієнтир у майбутній роботі полягає в удосконаленню такого типу підручників.

\section{Література}

1. Брацки А. Латиница в украинских рекламных текстах / А. Брацки // Письменность славян : прошлое, настоящее, будущее. Доклады Международного научнодидактического семинара (Гданьск, 2-4 марта 2006). - Красноярск, 2006. - С. 127-139.

2. Брацкі А. Мова як наукова і творча інспірація - український вимір / А. Брацкі // Українське мовознавство. - К., 2012. - Вип. 42/1. - С. 22-25.

3. Брацкі А. Національна філологія і славістика - співіснування чи суперництво? / А. Брацкі // Наукові записки. Серія : Філологічна.- Острог, 2010. - Вип. 15. - С. 65-72.

4. Брацки А. Русский язык как иностранный, изучаемый польскими студентамиславистами / А. Брацки // Русистика 2008. Язык, коммуникация, литература, культура. Шумен, 2009. - С. 93-100.

5. Брацкі А. Соціолінгвістична проблема двомовності в польських і українських дослідженнях / А. Брацкі // Європейський вимір української полоністики. Серія : Київські полоністичні студії. - К., 2007. - Т. ІХ. - С. 463-469.

6. Bracki A. Czasownik ukraiński. Podręcznik-vademecum dla cudzoziemców władających językiem polskim / A. Bracki, O. Pacejewska, N. Prysiażniuk. - Kijów, 2007.

7. Брацкі А. Сучасна мовна політика - польський досвід у слов'янському вимірі / А. Брацкі // Київські полоністичні студії. - К., 2013. - Т. XXII. - С. 399-404.

8. Bracki A. Międzykulturowość u Słowian jako typ przestrzeni polilingwalnej // «STUDIA LINGUISTICA». - К., 2012. - Вип. 6. - Ч. 2. - С. 410-416.

() А. 3. Брацкі, 2013. 
9. Bracki A. Misja folkloru jako nośnika zbiorowej pamięci narodu w kulturach słowiańskich - przyczynek do badań nad procesem krystalizowania się słowiańskich kultur narodowych / A. Bracki // «Folia Philologica Macedono-Polonica».- Skopje, 2011. - T. 8. S. 371-385.

10. Bracki A. Polityka językowa Imperium rosyjskiego i ZSRR na ziemiach ukraińskich jako przykład manipulowania historią poprzez jej interpretację / A. Bracki // Interpretacja historii - historia interpretacji / Red. A. Chodubski, H. Dubrzyńska, M. Krawczyński i in. Gdańsk, 2011. - T. I. - S. 179-194.

11. Bracki A. Postawa językowa jako typ manifestacji światopoglądu i przynależności społeczno-kulturowej / A. Bracki // Prace Komisji Językoznawczej Bydgoskiego Towarzystwa Naukowego. - Nr XX. Język - tekst - kultura / Pod red. H. Bartwickiej. Bydgoszcz, 2010. - S. 307-316.

12. Bracki A. Pragmatyka językowa a typ interferencji w obrębie języków blisko spokrewnionych - sposoby realizacji skrótów myślowych w wypowiedziach osób bilingwalnych / A. Bracki // Słowo z perspektywy językoznawcy i thumacza / Red. A Pstyga. Gdańsk, 2012. - T. IV. - S. 95-103.

13. Bracki A. Tłumacz jako sługa, pośrednik i twórca - w realizacji wariantu narodowego pierwowzoru literackiego / A. Bracki // Tłumacz: sługa, pośrednik, twórca? / Red. M. Guławska-Gawkowska, K Hejwowski, A. Szczęsny. Seria «Imago mundi». Warszawa, 2012. - S. 481-492.

14. Bracki A. Transformacja przestrzeni Europy Centralnej - aspekty socjolingwistyczne / А. Bracki // Київські полоністичні студії.- К., 2012. - Т. ХІХ. - С. 498-503.

15. Bracki A. Trenos Melecjusza Smotryckiego we współczesnej psycho- i socjolingwistycznej interpretacji / A. Bracki // «STUDIA LINGUISTICA».- K., 2011. Вип. 5. - С. 410-416,

16. Bracki A. Typowe błędy ortograficzne, gramatyczne, językowe, popełniane przy nauce języka polskiego / A. Bracki // «Славістичні записки». Журнал Тернопільского експериментального інституту педагогічної освіти.- Тернопіль, 1999. - № 1. - С. 102-104.

17. Bracki A. Wybrane problemy redakcji i przekładu Trenosu Melecjusza Smotryckiego / A. Bracki // Следите на словото. Юбилеен сборник в чест на проф. Дфн. Диана Иванова. - Пловдив, 2011. - С. 91-103.

18. Bracki A. Wybrane zagadnienia z zakresu problemów współczesnego języka polskiego (wykłady) // Програми спецкурсів та спецсемінарів слов’янського відділення філологічного факультету Київського національного університету ім. Тараса Шевченка / Упоряд. Г. Вервес, А. Брацкий і ін. - К., 1999. - С. 40-42. 